\title{
THE STUDY ON EFFECTIVENESS AND FLOW CHARACTERISTIC OF GRASSED SWALE DRAINAGE SYSTEM IN UTHM
}

\author{
Noor Aliza Ahmad ${ }^{1, a^{*}}$, Nurhazirah Mustaffa ${ }^{2, b}$, Mohd Adib Mohammad Razi, ${ }^{3, c}$, \\ Azra Munirah Mat Daud ${ }^{4, \mathrm{~d}}$, Sabariah Musa ${ }^{5, \mathrm{e}}$, Nurfarehan Zamanhuri, ${ }^{\text {,f }}$ \\ ${ }^{1,3,4,5}$ Faculty of Civil and Environmental Engineering \\ Department of Water and Environmental Engineering \\ Universiti Tun Hussein Onn Malaysia, 86400 Parit Raja, Batu Pahat, Johor \\ ${ }^{2,6}$ Student of Faculty of Civil and Environmental Engineering, UTHM \\ aaliza@uthm.edu.my, beyramusseth@gmail.com, cadib@uthm.edu.my, \\ dazra@uthm.edu.my, esabariah@uthm.edu.my, 'nurarean89@gmail.com
}

Keywords : grass swale; drainage system; hydraulic coefficient

\begin{abstract}
The drainage system is an infrastructure that requires systematic planning of construction which can function properly to reduce the risk of flooding. Flooding occurs due to the rapid development resulting in lack of permeable surfaces. This will lead to increase the surface runoff, where the flow velocity and flow discharge also will be increased. Therefore, grassed swale is one of the sustainable drainage systems that can be applied to solve this problem. This study aims to identify the effectiveness of the grassed swale drainage system at Universiti Tun Hussein Onn Malaysia (UTHM), to determine the hydraulic characteristics and the effectiveness of vegetation used in the swale drainage system. Through this approach, the solution of past studies, related journals, and Manual Saliran Mesra Alam (MSMA) [1] are used as a reference for this study. Data collection was conducted on grassed Swale with total length 60 meters. To obtain an accurate data, measurements of flow velocity have been taken three times, and for three days after raining. Data was observed by 81 times and analyzed using the Manning's equation. Manning's equation was adopted to determine the value of hydraulic coefficients for the grass swale channel. The results obtained, demonstrates that the value of Manning's $n$ for all sections is stated in a range of 0.015 to 0.030 . The results also showed a difference in the size of the design, the flow velocity, the water depth, and the flow discharge of the grassed swale drainage system.
\end{abstract}

\section{Introduction}

The drainage system is an infrastructure system which is so important, especially in urban areas. Planning the construction of systematic drainage system must be designed to function properly in order to reduce the risk of flooding [1]. Increased rapid development will give effect to the existing drainage system. The impact of development will result in the reduction of permeable surfaces, increased runoff flows towards the catchment area, increased the peak flood discharge, and declined the water quality. Besides that, deposition and disposition waste and pollutants will occur when it rains.

The rise of technology has created a system that is more environmentally-friendly drainage system using grass that covered the top of the drainage system. These drainage systems are widely used in Malaysia, for example, at Universiti Sains Malaysia (USM), Putrajaya, and Universiti Tun Hussein Onn Malaysia (UTHM). Various benefits derived from the use of this MSMA system, which are able to reduce the quantity of runoff, improve the water quality that flows into the catchment area, reduce the risk of clogging drainage, and thus reduce the flood risk. This study was conducted at the UTHM campus and focus on the effectiveness of wet grassed swale and its hydraulic performance. The hydraulic parameters involved in this study are flow depth, flow velocity, flow discharge, and cross-sectional area. The objectives for this study are to identify the effectiveness of the grassed swale drainage system at Universiti Tun Hussein Onn Malaysia 
(UTHM), to analyze the effect of vegetation used in the drainage system of swale, and to determine the hydraulic characteristics that involved in grassed swale drainage system. Figure 1 shows the conditions of swale during wet and dry.
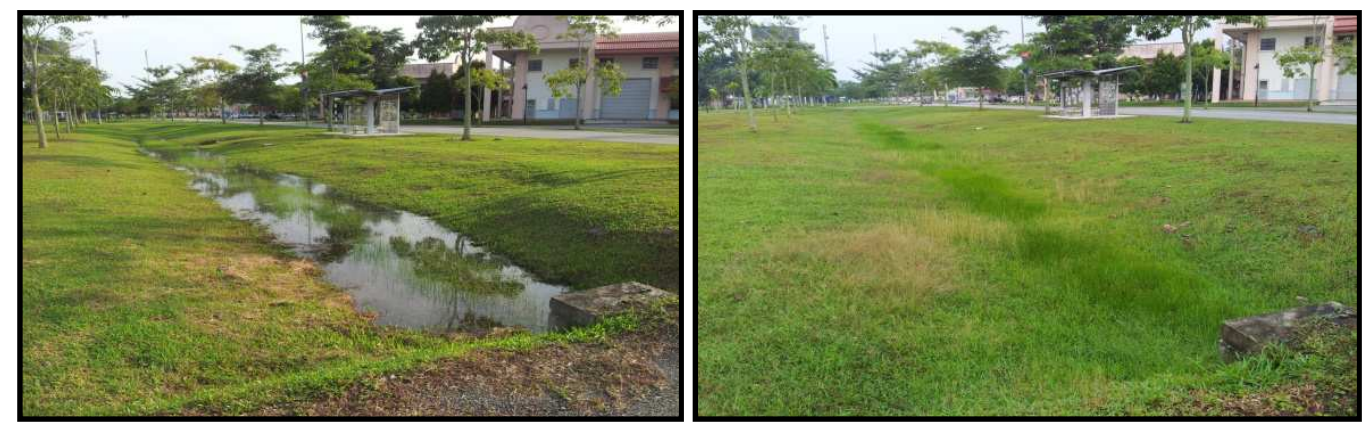

Figure 1: Swale during wet and dry conditions

\section{Materials and Method}

Data collection was conducted at grassed swale around the Universiti Tun Hussein Onn Malaysia (UTHM) campus. Length of the Swale at site of study is 60 meters and divided into three sections, which are Section A, Section B, and Section C. The equipment used to collect the data is as shown in Figure 2.

i) Current Meter Flow - measures the energy of moving water and translates it into a flow velocity [2]. Current meters can measure velocity very accurately, provided that they are used correctly [2].

ii) Levelling instrument - to find the cross section of swales and to understand the design of wet swales where it cannot be measured using a measuring tape.

iii) Measuring tape - measures the width and depth of surface drainage [3].

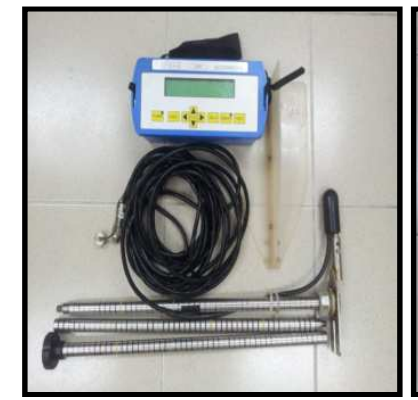

(i) Current Meter Flow

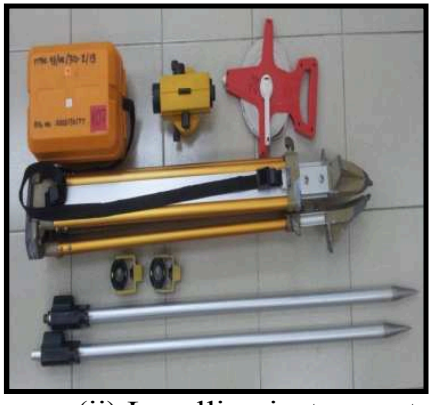

(ii) Levelling instrument

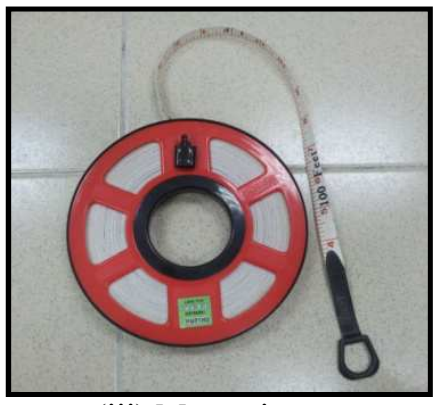

(iii) Measuring tape

Figure 2: The equipment used to collect data at site study

\section{Data Collection}

Data was collected after the rainfall event. The data were taken from the field, where selected equipment is used to obtain the required data. Equipment that used to gain the data are Current Meter Flow, Depth Sounder and levelling instrument [4]. The data obtained in this field are:

i) Area of the swale, A

ii) Flow velocity in the swale, $\mathrm{V}$

iii) Wet perimeter of the swale, $P$

iv) Depth of the swale, Y

v) Top width of the swale, $\mathrm{T}$

This study has been divided into three sections, Section A, Section B, and Section C. Distance from Section A to Section B is 30 meter and Section B to Section C is also 30 meters. Figure 3, Figure 4, and Figure 5 show the cross section of swales at Section A, Section B, and Section C. Figure 6 shows the distribution of flow to every section. 


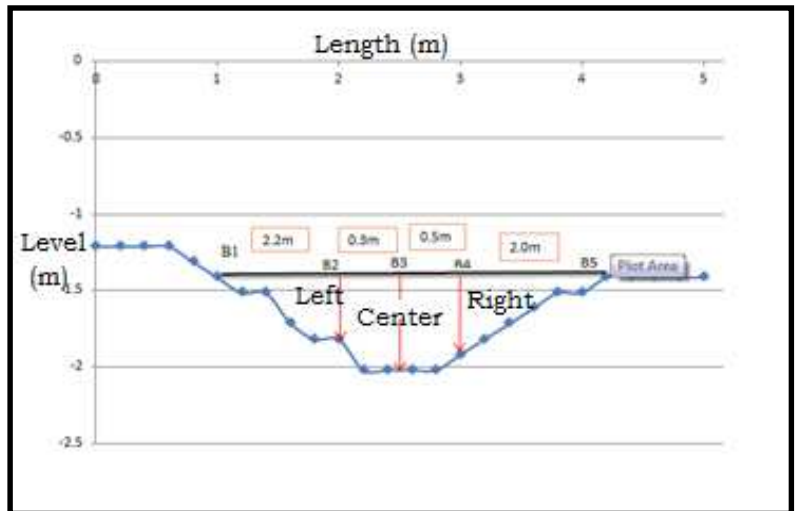

Figure 3 : Cross section for wet swale at Section A

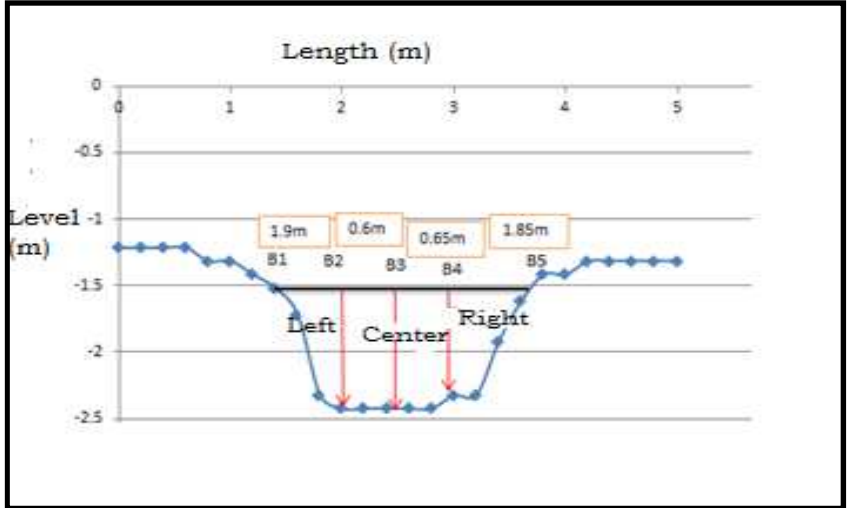

Figure 4 : Cross section for wet swale at Section B

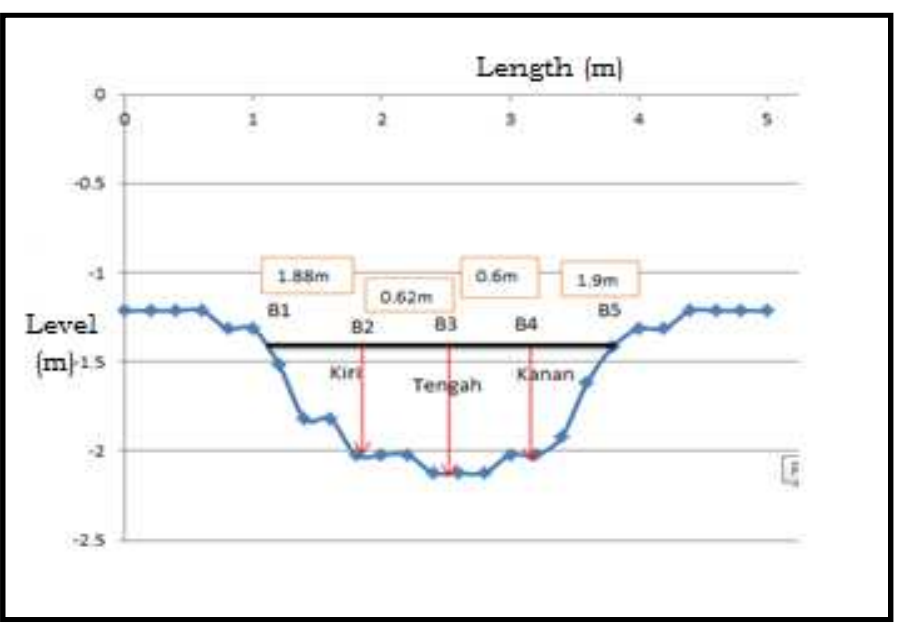

Figure 5: Cross section for wet Swale in Section C

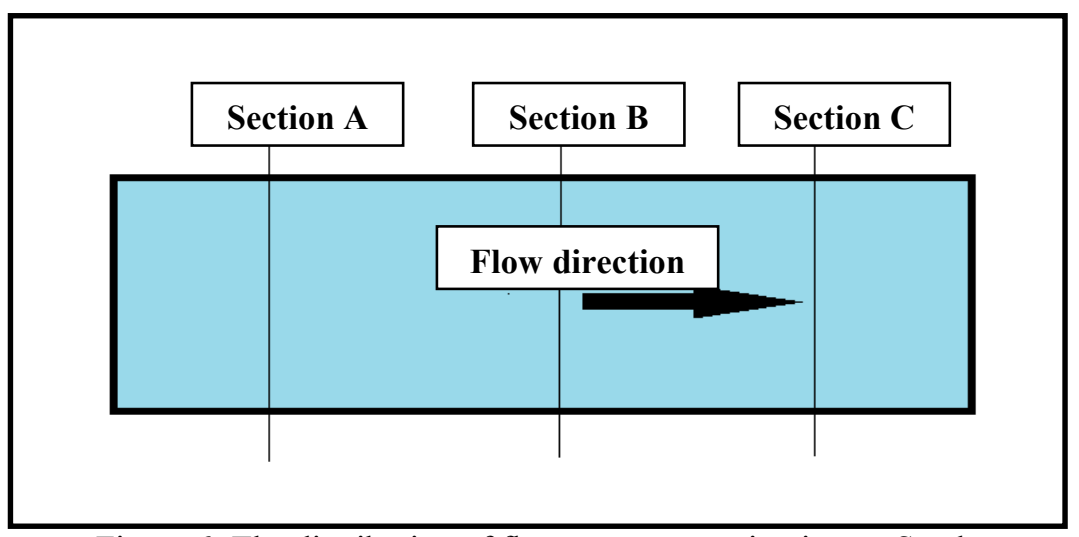

Figure 6: The distribution of flow to every section in wet Swale

Table 1 shows the details of swale profile at three sections. Land surveying was conducted at all three sections to gain the cross section of the swales. This data are important in terms of determining the effectiveness of the swale.

Table 1 : Details of swale profile at three sections

\begin{tabular}{|l|c|c|c|}
\hline \multicolumn{1}{|c|}{ Cross Section } & A & B & C \\
\hline Top width (m) & 5.0 & 5.0 & 5.0 \\
\hline Bottom width (m) & 1.4 & 1.4 & 1.6 \\
\hline Area $\left(\mathrm{m}^{2}\right)$ & 0.292 & 1.241 & 0.879 \\
\hline Maximum water level (m) & 0.63 & 0.63 & 0.65 \\
\hline Minimum water level (m) & 0.20 & 0.37 & 0.25 \\
\hline
\end{tabular}




\section{Result and Conclusion}

The results are formed by the data that taken from the swale which divided into three sections, on three different days, in which the data is taken shortly after the rainfall event. The average value of the flow velocity and flow discharge is determined by using the appropriate hydraulic formulas. Table 2 shows the average value of flow velocity and flow discharge at three sections of swale for three days. The value of Manning's (n) for the grassed swale in this study is in the range of 0.015 to 0.030 .

Table 2 : Flow discharge and velocity at three sections of swale for three days

\begin{tabular}{|c|c|c|c|}
\hline Section & Day & Flow discharge, $Q\left(\mathrm{~m}^{3} / \mathrm{s}\right)$ & Velocity, V (m/s) \\
\hline \multirow{3}{*}{ A } & 16 March 2014 & 0.129 & 0.445 \\
\hline & 03 April 2014 & 0.126 & 0.485 \\
\hline & 15 April 2014 & 0.146 & 0.448 \\
\hline \multirow{3}{*}{ B } & 16 March 2014 & 0.129 & 0.429 \\
\hline & 03 April 2014 & 0.126 & 0.479 \\
\hline & 15 April 2014 & 0.146 & 0.446 \\
\hline \multirow{3}{*}{$\mathrm{C}$} & 16 March 2014 & 0.533 & 0.434 \\
\hline & 03 April 2014 & 0.126 & 0.479 \\
\hline & 15 April 2014 & 0.337 & 0.446 \\
\hline
\end{tabular}

Based on the table, the highest flow discharge of the swale occurs at Section $\mathrm{C}$ with a value of $0.533 \mathrm{~m}^{3} / \mathrm{s}$ on $16^{\text {th }}$ March 2014 . Meanwhile, on $3^{\text {rd }}$ April 2014, the lowest value of flow discharge is $0.126 \mathrm{~m} 3 / \mathrm{s}$, where occurred at all sections. The highest average flow velocity of swale is occurring in Section A with value of $0.485 \mathrm{~m} / \mathrm{s}$ on $3^{\text {rd }}$ April 2014 . Meanwhile, the lowest average flow velocity is $0.429 \mathrm{~m} / \mathrm{s}$, where occurred in Section B. From this analysis, it shows that Section B is the most effective section of the swale. Section B proves that if the velocity is reduced, the flow discharge will reduce too. These results may be due to several factors in terms of the profile depth, the profile area, and the type of vegetation that grow in that section of the swale. Figure 10, Figure 11 and Figure 12 shows the graph of flow discharge versus velocity at each Section A, Section B, and Section $\mathrm{C}$ for three days.

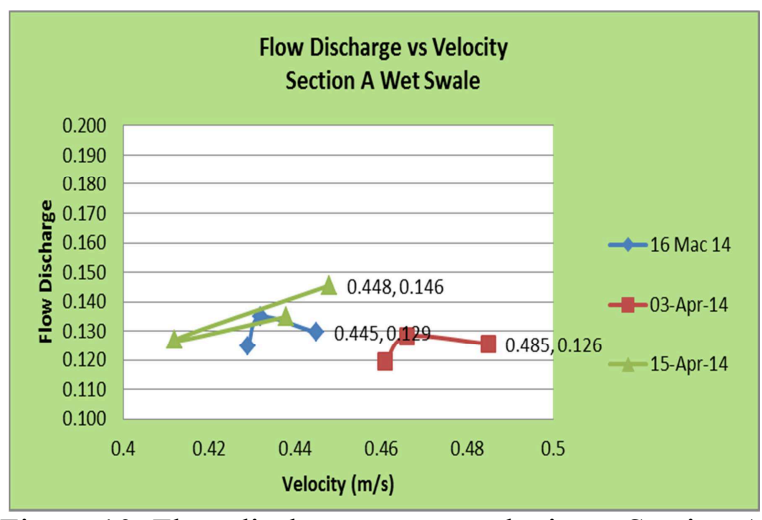

Figure 10: Flow discharge versus velocity at Section A



Figure 11: Flow discharge versus velocity at Section B 


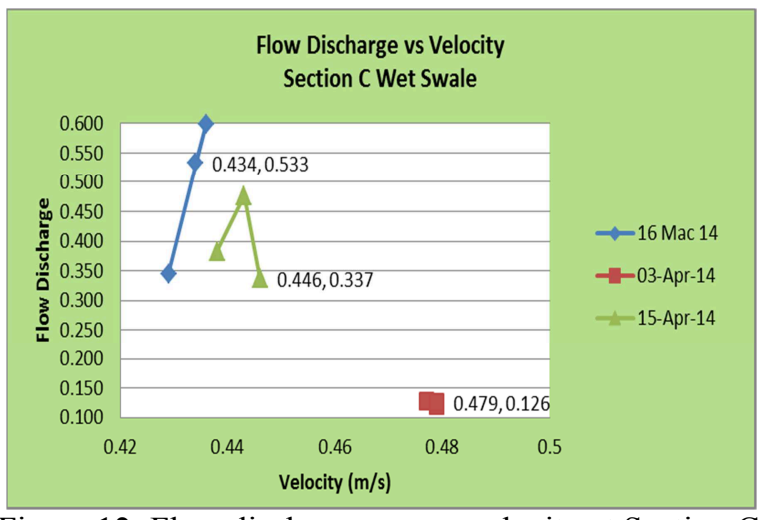

Figure 12: Flow discharge versus velocity at Section C

In conclusion, the effectiveness of the wet swale drainage system can be used to avoid flooding occurred, but the swale must be well designed with proper construction. This is because, based on the study, it shows that if the swale has appropriate profile depth and profile area, then the swale is effective to be used as a drainage system. Vegetation also plays an important role in the effectiveness of the swale. Vegetation is an important factor to act as an agent to slow down the flow velocity, thus reduced the flow discharge within the swale. Maintenance of wet Swale is required to ensure that the intended use of the grassed swale drainage system can be achieved, which are controlling the volume of surface runoff and avoiding flooding.

\section{Acknowledgements}

The authors would like acknowledgment the Ministry of Higher Education Malaysia and Universiti Tun Hussein Onn Malaysia (UTHM) for financially under FRGS Grants (vot:1414) for supporting this study.

\section{References}

[1] Manual Saliran Mesra Alam, Malaysia. MSMA $2^{\text {nd }}$ Edition. 2012.

[2] Georgia Stormwater Management Manual. Volume 2: Technical Handbook. 2001.

[3] Ven Te Chow. Open Channel Hydraulics. International Edition. Singapore. McGraw-Hill Companies. 1973.

[4] Jason T. Kirby, S. Rocky Durrans, Robert Pitt, Pauline D. Johnson. Hydraulic Resistance in Grass Swales Designed for Small Flow Conveyance. 2005.

[5] Ab Aziz Abdul Latiff, Mohd Adib Mohammad Razi, Noor Aliza Ahmad. Module Hidraulik UTHM. 2006.

[6] Richard H. French. Open Channel Hydraulics. International Edition. Singapore. McGraw-Hill Companies. 1994. 